\title{
Mercury accumulation in adolescents scalp hair and fish consumption: a case study comparing populations having natural or anthropogenic sources
}

\author{
H.C. Vieira, A.M.V.M. Soares, F. Morgado, S.N. Abreu \\ Department of Biology \& CESAM, University of Aveiro, 3810-193 Aveiro, Portugal
}

\begin{abstract}
The consumption of fish is usually considered the main route of contamination of mercury in humans. In a climate change scenario implying ocean acidification, mercury methylation is expected to increase leading to bioaccumulation increments in the food chain, affecting mainly coastal populations. In this study, mercury accumulation and fish consumption was evaluated considering mercury concentrations in human scalp hair in relation to fish consumption habits in adolescents (16 to 21 years old) from two coastal areas: Angra do Heroísmo and Aveiro (respectively a city in the Azores islands, and a mainland portuguese coastal city), presenting similar mercury levels in the surrounding coastal environments (0.1-0.3 $\mathrm{g} \mathrm{g} \mathrm{g}^{-1}$ in surface fine sediments) in spite of the mercury source (being from natural causes in the first site and anthropogenic in the second).

Total mercury ( $\mathrm{THg}$ ) determination was performed by atomic absorption spectrometry with the Advanced Mercury Analyzer (AMA-254, LECO), and the analytical quality of the procedure was checked using reference materials TORT-2. The surveyed young populations showed similar fish consumption habits ( 0 to 6 meals in a week schedule) and revealed mercury concentrations in scalp hair ranging from 0.79 to $1.82 \mu \mathrm{g}$ $\mathrm{g}^{-1}$. In spite of being young population consumers, results show a pattern of increased mercury concentration with increasing fish consumption habits.
\end{abstract}

Keywords: adolescent fish consumers, Azores, human scalp hair, mercury, mercury accumulation.

\section{Introduction}

Mercury $(\mathrm{Hg})$ is a ubiquitous and persistent trace metal in environment, making it one of the most hazardous elements, especially in the marine environments (Hajeb et al. 2008, Palma et al. 2009, Freire et al. 2010, Raimundo et al. 2010).

In the environment mercury is released from natural processes (eg. volcanic activity) and anthropogenic sources (eg. industrial processes) (Agusa et al. 2005, Freire et al. 2010). The intense geotectonic activity, that includes volcanic eruptions, geothermal vents, and degassing from the earth's crust, is described as an important natural source of $\mathrm{Hg}$ (Amaral et al. 2006, Amaral et al. 2008, Hajeb et al. 2008, Palma et al. 2009). A part of the emitted components (in particular, $\mathrm{Hg}, \mathrm{S}$, trace elements, and others) is a priori considered juvenile products.

The majority of $\mathrm{Hg}$ released into the marine environment is inorganic but can be converted to the organic mercury by aerobic and anaerobic bacteria (Cizdziel and Gerstenberger 2004, Raimundo et al. 2010).

Mercury uptake by marine organisms is a cumulative process resulting of bioaccumulation and biomagnifications through the food webs. The biomagnification of mercury along the food chain has as last target humans, representing a serious problem for human health (Dolbec et al. 2001, Agusa et al. 2005, Harmelin-Vivien et al. 2009. Humans can accumulate mercury from amalgam fillings, thermometers and cosmetics products, but the main source of mercury exposure for human population is through consumption of seafood, fish and other marine animals (Holsbeek et al. 1996, Al-Majed and Preston 2000, Olivero et al. 2002, Díez et al. 2008, Freire et al. 2010).

The scalp hair has been used in many studies as a bioindicator of mercury exposure for humans populations (Dolbec et al. 2001, Freire et al. 2010). The hair grows approximately $1 \mathrm{~cm}$ each month and the mercury penetrates into the hair follicles and becomes stable providing the history of expose, therefore the levels closest to the scalp reflects the most recent exposure. (Dolbec et al. 2001, Agusa et al. 2007, Díez et al. 2008, Freire et al. 2010) There are several reasons to used hair as an indicator for mercury exposure: (1) it is easy to collect in a non-invasive manner (2) it captures temporal exposure history as $\mathrm{Hg}$ is incorporated into growing hair (3) it does not require special facilities for transport or storage (Vladimír 1995, Cizdziel and Gerstenberger 2004). 
The aim of this study was to evaluate the influence of fish consumption on $\mathrm{THg}$ levels of young consumers, selecting two different coastal populations inhabiting areas affected by dissimilar mercury sources.

In the Azores the major industry is scarce which means that there is not a significant industrial discharge into the environment of this metal as happens in the mainland. Instead, Azores archipelago (of volcanic origin) has active zones (hydrothermal activity), which makes the likely source of mercury found in its coastal areas being from natural processes (Andersen and Depledge 1997, Afonso et al. 2007).

\section{Materials and Methods}

\section{Sampling sites}

The choices of the cities of Aveiro and Angra do Heroísmo were based on their different mercury source, geographical localization and socioeconomic characteristics. Aveiro city is located in the Portuguese mainland, and characterized mainly by industrial activities with a significant number of potential focuses of environmental pollutants that include one chlor-alkali plant. In spite of showing confined hot spots of mercury contamination inside a coastal lagoon (Abreu et al., 2000), Aveiro open sea coastal waters have relatively low mercury concentration $\left(<0.3 \mu \mathrm{g} \mathrm{g} \mathrm{g}^{-1}\right.$ in surface fine sediments, Pereira et al., 2009). On the other side, Angra do Heroísmo is a small city located in Terceira Island on the Azores archipelago, where industrial activity is scarce, and fishery and agriculture are the main economic activities.

\section{Hair collection and analytical procedure}

Hair samples were collected from donors by a single cutting from the occipital region using a clean stainless steel scissor. Human scalp hair samples were collected from young people aged $16-21$ years, of two different sites Aveiro $(n=49)$ and Terceira Island $(n=36)$. During collection of the hair samples, each individual was asked to complete a questionnaire detailing age, gender, body weight, height, smoking habits and frequency of fish consumption.

The hair samples were then kept in clean microtubes of $2 \mathrm{ml}$, identified appropriately and transported to the laboratory.

Mercury was quantified by atomic absorption spectrometry with the Advanced Mercury Analyzer (AMA-254, LECO). The analytical quality of the procedure was checked using reference materials such as TORT-2 (Lobster Hepatopancreas Reference Material for Trace Metals, National Research Council of Canada).

\section{Statistical analysis}

For the statistical analysis outliers have been removed. The data normality of mercury concentration was examined through Shapiro-Wilk test. The test showed the mercury concentration not normally distributed. Therefore, we used non-parametric statistical methods, Wilcoxon Rank sum test and the Kruskal-Wallis test to compare the mean of mercury concentration among the categories (local, age, gender, smoking habits and fish consumption). Spearman correlation coefficients were used to test the correlation between variables. Statistical analyses were realized using SPSS (version 15.0). Statistical significance was defined as $\mathrm{p}<0.05$.

\section{Results and Discussion}

In this study the overall mean of the mercury concentration found in the hair samples was $0.79 \pm 0.04 \mu \mathrm{g}$ $\mathrm{g}^{-1}$ and the maximum value found was $1.82 \mu \mathrm{g} \mathrm{g}^{-1}$ (Fig. 1). These values being in the range $1-2 \mu \mathrm{g} \mathrm{g}^{-1}$.are considered standard by the World Health Organization (WHO).

The comparison of the two populations in relation to fish consumption rate, sampling site, age, gender and smoking habits is summarized in Table I.

Table 1. Hair mercury levels according to age, gender, smoking habits, fish consumption and fish meals per week.

\begin{tabular}{cccc} 
& \multicolumn{3}{c}{ Hair mercury $\left(\mu g^{-1}\right)$} \\
\cline { 2 - 4 } Variables & $\mathrm{n}(\%)$ & Mean \pm S.E & Max - Min \\
\hline Age (years) & $5(5.8)$ & $0.54 \pm 0.18$ & $1.23-0.18$ \\
16 & $28(32.9)$ & $0.69 \pm 0.05$ & $1.17-0.24$ \\
17 & $42(49.4)$ & $0.83 \pm 0.06$ & $1.77-0.17$ \\
18 & $7(8.3)$ & $1.06 \pm 0.20$ & $1.82-0.61$ \\
19 & $3(3.5)$ & $0.88 \pm 0.15$ & $1.18-0.72$ \\
21 & & & \\
Gender & $48(56.5)$ & $0.80 \pm 0.05$ & $1.77-0.17$ \\
Female & $37(43.5)$ & $0.77 \pm 0.06$ & $1.82-0.24$ \\
Male & & & \\
Smoker & $61(71.8)$ & $0.81 \pm 0.05$ & $1.82-0.17$ \\
No & $24(28.2)$ & $0.73 \pm 0.07$ & $1.70-0.18$ \\
Yes & & & \\
Fish consumption & $8(9.4)$ & $0.56 \pm 0.11$ & $1.28-0.24$ \\
No & $77(90.6)$ & $0.81 \pm 0.04$ & $1.82-0.17$ \\
Yes & & & \\
Meals/week & $8(9.4)$ & $0.56 \pm 0.11$ & $1.28-0.24$ \\
0 & $39(45.9)$ & $0.74 \pm 0.07$ & $1.62-0.17$ \\
1 & $31(36.4)$ & $0.84 \pm 0.07$ & $1.77-0.23$ \\
2 & $7(8.3)$ & $1.01 \pm 0.19$ & $1.82-0.40$ \\
3 & & &
\end{tabular}

The average of mercury hair concentration was $0.86 \pm 0.05 \mu \mathrm{g} \mathrm{g}^{-1}$ in the Mainland and $0.69 \pm 0.05 \mu \mathrm{g} \mathrm{g}^{-1}$ in Terceira Island suggesting higher mercury levels in mainland compared to data from Terceira Island. According the U.S EPA's references of dose (RfD) corresponds to approximately $1 \mu \mathrm{g} \mathrm{g}^{-1}$ of total mercury in hair (USEPA 1997), in this study $18.4 \%$ of the population in Terceira island and $23.7 \%$ in the Mainland, exceed this safety standard 

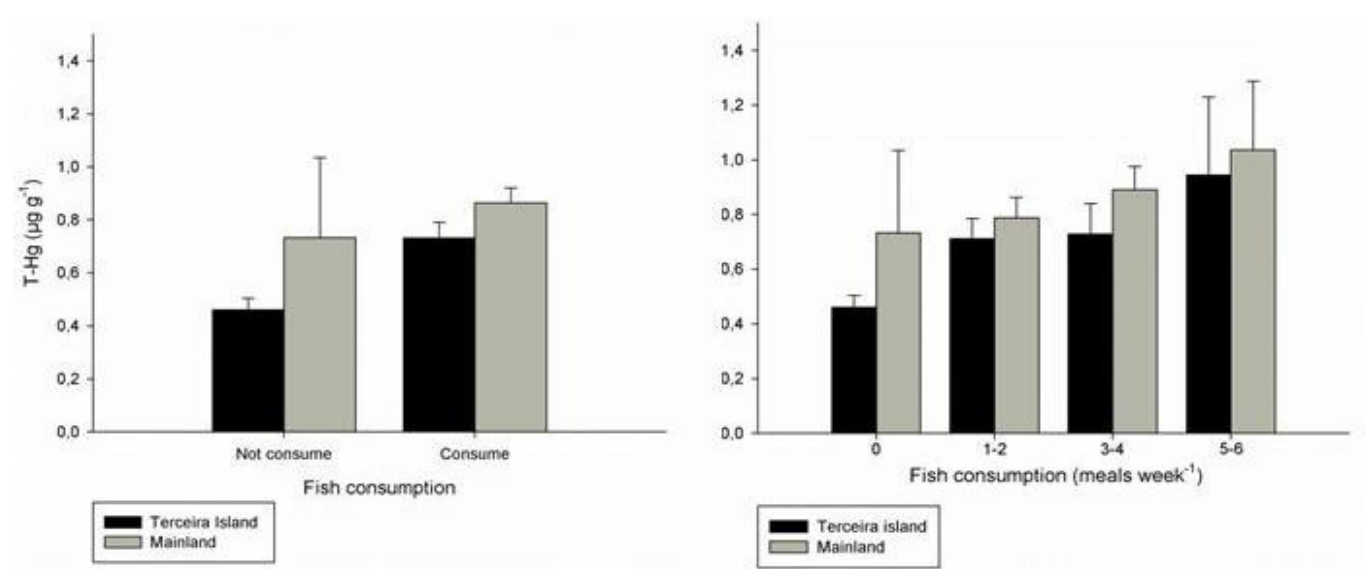

Fig. 1. Distribution of hair mercury by fish consumption in both stations.

Considering all volunteers $(\mathrm{n}=85)$, the mean of mercury level for gender in females $\left(0.80 \pm 0.05 \mu \mathrm{g} \mathrm{g}^{-1}\right)$ was relatively higher than in males $\left(0.77 \pm 0.06 \mu \mathrm{g} \mathrm{g}^{-1}\right)$. Evaluating separately each sampling site, the pattern found in Terceira Island are in accordance with, Agusa et al. (2005) and Hajeb et al. (2008) females exhibits a higher level $\left(0.72 \pm 0.07 \mu \mathrm{g} \mathrm{g}^{-1}\right)$ in hair than males $\left(0.66 \pm 0.08 \mu \mathrm{g} \mathrm{g}^{-1}\right)$. Instead, in the Mainland the levels found in males $\left(0.87 \pm 0.09 \mu \mathrm{g} \mathrm{g}^{-1}\right)$ were higher than females $\left(0.85 \pm 0.07 \mu \mathrm{g} \mathrm{g}^{-1}\right)$ according to the Saeki et al. (1996), and Yasutake et al. (2003). Overall mercury concentrations in hair scalp show significant differences $(p<0.05)$ between sampling sites, indicating possible differences due to the site specificity, indicating a bioconcentration process increasing (by a factor of 4 in both sites) the T-Hg levels from the abiotic compartment.

A statistically significant difference $(p<0.05)$ was obtained comparing hair mercury levels between "not eating" and "eating fish" groups, and among "eating fish" sub-groups but only in the Terceira Island populations. No statistically significant difference $(\mathrm{p}>0.05)$ was found in hair mercury concentrations among the Aveiro "no eating", "fish eating" groups, nor among "eating" sub-groups with diverse fish consumption rates, although overall data (independently from site) indicates a statistical differences $(p<0.05)$ in both analysis.

Considering the age factor, in spite of the narrow age range considered (16 to 21 years), a positive correlation $(p<0.05)$ between age and T-Hg in hair was found on each population and when correlating overall data, revealing mercury bioaccumulation processes in adolescents, a crucial phase of human life development.

\section{Conclusion}

Fish consumption was a significant source of mercury accumulation in the two coastal populations; in spite of being young population consumers. Overall results show a pattern of increased mercury concentration with increasing age and fish consumption habits.

Mercury level in this study did not exceed NOAEL of WHO. The levels remains relatively low and risk alert of the mercury exposure should not be considered. Ongoing studies will increase the number of sample providing more reliable conclusions.

\section{Acknowledgements}

The authors thank the financial supports providing from Post-Doc grant (S.N. Abreu SFRH / BPD / 45807 / 2008).

\section{References}

Abreu, S. N., Pereira, E., Vale, C., \& Duarte, A. C., 2000. Accumulation of mercury in sea bass from a contaminated lagoon (Ria de Aveiro, Portugal). Marine Pollution Bulletin, 40(4), 293-297.

Afonso, C., H. M. Lourenço, A. Dias, M. L. Nunes, and M. Castro. 2007. Contaminant metals in black scabbard fish (Aphanopus carbo) caught off Madeira and the Azores. Food Chemistry 101:120-125.

Agusa, T., T. Kunito, H. Iwata, I. Monirith, C. Chamnan, T. S. Tana, A. Subramanian, and S. Tanabe. 2007. Mercury in hair and blood from residents of Phnom Penh (Cambodia) and possible effect on serum hormone levels. Chemosphere 68:590-596.

Agusa, T., T. Kunito, H. Iwata, I. Monirith, T. S. Tana, A. Subramanian, and S. Tanabe. 2005. Mercury contamination in human hair and fish from Cambodia: levels, specific accumulation and risk assessment. Environmental Pollution 134:79-86.

Al-Majed, N. B. and M. R. Preston. 2000. Factors influencing the total mercury and methyl mercury in the hair of the fishermen of Kuwait. Environmental Pollution 109:239-250.

Amaral, A., V. Rodrigues, J. Oliveira, C. Pinto, V. Carneiro, R. Sanbento, R. Cunha, and A. Rodrigues. 
2006. Chronic exposure to volcanic environments and cancer incidence in the Azores, Portugal. Science of The Total Environment 367:123-128.

Amaral, A. F. S., M. Arruda, S. Cabral, and A. S. Rodrigues. 2008. Essential and non-essential trace metals in scalp hair of men chronically exposed to volcanogenic metals in the Azores, Portugal. Environment International 34:1104-1108.

Andersen, J. L. and M. H. Depledge. 1997. A survey of total mercury and methylmercury in edible fish and invertebrates from Azorean waters. Marine Environmental Research 44:331-350.

Cizdziel, J. V. and S. Gerstenberger. 2004. Determination of total mercury in human hair and animal fur by combustion atomic absorption spectrometry. Talanta 64:918-921.

Díez, S., P. Montuori, A. Pagano, P. Sarnacchiaro, J. M. Bayona, and M. Triassi. 2008. Hair mercury levels in an urban population from southern Italy: Fish consumption as a determinant of exposure. Environment International 34:162-167.

Dolbec, J., D. Mergler, F. Larribe, M. Roulet, J. Lebel, and M. Lucotte. 2001. Sequential analysis of hair mercury levels in relation to fish diet of an Amazonian population, Brazil. Science of The Total Environment 271:87-97.

Freire, C., R. Ramos, M.-J. Lopez-Espinosa, S. Díez, J. Vioque, F. Ballester, and M.-F. Fernández. 2010. Hair mercury levels, fish consumption, and cognitive development in preschool children from Granada, Spain. Environmental Research 110:96-104.

Hajeb, P., J. Selamat, A. Ismail, F. Bakar, J. Bakar, and H. Lioe. 2008. Hair mercury level of coastal communities in Malaysia: a linkage with fish consumption. European Food Research and Technology 227:1349-1355.

Harmelin-Vivien, M., D. Cossa, S. Crochet, D. Bănaru, Y. Letourneur, and C. Mellon-Duval. 2009. Difference of mercury bioaccumulation in red mullets from the north-western Mediterranean and Black seas. Marine Pollution Bulletin 58:679-685.

Holsbeek, L., H. K. Das, and C. R. Joiris. 1996. Mercury in human hair and relation to fish consumption in Bangladesh. Science of The Total Environment 186:181-188.

Olivero, J., B. Johnson, and E. Arguello. 2002. Human exposure to mercury in San Jorge river basin, Colombia (South America). Science of The Total Environment 289:41-47.

Palma, C., A. I. Lillebo, M. Valenca, E. Pereira, M. P. Abreu, and A. C. Duarte. 2009. Mercury in sediments of the Azores deep sea platform and on sea mounts south of the archipelago--assessment of background concentrations. Mar Pollut Bull 58:1583-1587.

Pereira M.E., Lillebø A. I., Pato P., Válega M., Coelho J. P., Lopes C.B., Rodrigues S., Cachada A., Otero M., Pardal M. A., Duarte A. C., 2009. Mercury pollution in Ria de Aveiro (Portugal): a review of the system assessment. Environ Monit Assess, 155:39-49.

Raimundo, J., C. Vale, J. Canário, V. Branco, and I.
Moura. 2010. Relations between mercury, methyl-mercury and selenium in tissues of Octopus vulgaris from the Portuguese Coast. Environmental Pollution 158:2094-2100.

Saeki, K., M. Fujimoto, D. Kolinjim, and R. Tatsukawa. 1996. Mercury concentrations in hair from populations in Wau-Bulolo area, Papua New Guinea. Archives of Environmental Contamination and Toxicology 30:412-417.

USEPA. 1997. Mercury Study Report to Congress IV. An Assessment of Exposure to Mercury in the United States. Office of Air Quality Planning and Standards and Office of Research and Development, Washington, DC.

Vladimír, B. 1995. Use of human hair as a biomarker in the assessment of exposure to pollutants in occupational and environmental settings. Toxicology 101:29-39.

Yasutake, A., M. Matsumoto, M. Yamaguchi, and N. Hachiya. 2003. Current hair mercury levels in Japanese: survey in five districts. Tohoku J Exp Med 199:161-169. 